\author{
Barbara MARKIEWICZ ${ }^{1}$ \\ Leonard ZIEMIAŃSKI ${ }^{2}$
}

\title{
ANALIZA DYNAMICZNA KOMPOZYTOWYCH KONSTRUKCJI CIENKOŚCIENNYCH
}

\begin{abstract}
W pracy przedstawiono analizę dynamiczną kompozytowej konstrukcji cienkościennej o przekroju zamkniętym prostokątnym, o różnych schematach statycznych. Do analizy wykorzystano modele powłokowe i odpowiadające im uproszczone modele prętowe. W modelach powłokowych uwzględniona została ortotropia materiału kompozytowego i różne warianty ułożenia włókien nośnych w poszczególnych warstwach. W modelach belkowych dokonano homogenizacji materiału uzyskując materiał izotropowy o średniej sztywności zastępczej. W analizie uwzględniono dodatkowe usztywnienia w postaci przepon wewnętrznych. Analizowano częstotliwości własne i odpowiadające im postacie drgań. Zbadano jaki wpływ na wyniki ma kąt orientacji włókien w warstwach, smukłość belki i schemat statyczny oraz porównano wyniki otrzymane dla modeli powłokowych z wynikami otrzymanymi dla uproszczonych modeli prętowych.
\end{abstract}

Słowa kluczowe: pręt kompozytowy, pręt cienkościenny, model prętowy, modelowanie MES, dynamika, częstotliwości drgań

\section{Wprowadzenie}

Zainteresowanie kompozytami wynika bezpośrednio $\mathrm{z}$ ich zalet $\mathrm{tj}$. ich duża wytrzymałość przy niewielkim ciężarze, odporność na korozję i na działanie czynników zewnętrznych, łatwość formowania i uzyskiwania różnorodnych kształtów. To właśnie dzięki doskonałym parametrom kompozyty są od lat wykorzystywane w przemyśle lotniczym, samochodowym i stoczniowym, a od ok. 30 lat także coraz częściej w budownictwie. Najczęstsze przykłady konstrukcji z kompozytów to: maszty, turbiny wiatrowe, obiekty mostowe, kładki dla pieszych, ale istnieją również inne obiekty, których cała konstrukcja nośna wykonana jest z profili kompozytowych, jak budynek Eyecatcher w Szwajcarii [1].

\footnotetext{
${ }^{1}$ Autor do korespondencji / corresponding author: Barbara Markiewicz, Politechnika Rzeszowska, Katedra Mechaniki Konstrukcji, ul. Poznańska 2, 35-959 Rzeszów; tel. 178651618; bmarkiewicz@ prz.edu.pl ${ }^{2}$ Leonard Ziemiański, Politechnika Rzeszowska, Katedra Mechaniki Konstrukcji, ul. Poznańska 2, 35-959 Rzeszów; tel. 178651353; ziele@ @rz.edu.pl
} 
Wykorzystanie kompozytów pozwala na budowę konstrukcji smuklejszych i lżejszych niż dotychczas, ale równocześnie bardziej wrażliwych na działanie obciążeń dynamicznych. W skrajnych wypadkach obciążenia te mogą zagrażać bezpieczeństwu i trwałości konstrukcji. Konieczne jest zatem dobre zrozumienie dynamicznego zachowania konstrukcji i jej elementów, co oznacza wzrost udziału analizy dynamicznej w projektowaniu konstrukcji [2].

\section{Analiza dynamiczna $\mathrm{z}$ wykorzystaniem modeli prętowych}

Nie wszystkie parametry są niezbędne do modelowania danego zagadnienia, a ich zbyt duża ilość utrudnia ocenę modelu i znalezienie ewentualnych błędów. Ważne jest poznanie i zrozumienie analizowanego zjawiska czy zachowania obiektu na tyle, by móc wybrać tylko istotne do budowy modelu dane.

Pomimo, że każdy element jest trójwymiarowy to w praktyce inżynierskiej przyjęto uproszczenia modelu $\mathrm{w}$ zależności od dominujących wymiarów, np. belka, która ma dominujący jeden wymiar, modelowana jest jako element jednowymiarowy. Wielu autorów z powodzeniem do modelowania zagadnień trójwymiarowych, niekiedy nawet o skomplikowanej strukturze wewnętrznej, stosuje model jednowymiarowy w postaci pręta zginanego i skręcanego [3-5]. Podejście to stosuje się zarówno do modelowania konstrukcji cienkościennych [3,4], modelowania regularnych konstrukcji prętowych [5], jak i modelowania konstrukcji kompozytowych [9-14].

Wymieniając najbardziej powszechnie stosowane modele prętowe należy zacząć od klasycznej belki Eulera-Bernoulliego [6]. Stosuje się dla niej założenie płaskich przekrojów tj. przekrój płaski przed odkształceniem pozostaje płaski, tej samej długości i prostopadły do osi pręta po odkształceniu. Założenie to nie uwzględnia jednak wpływu siły poprzecznej i nie sprawdza się w przypadku opisu belek krępych.

Bardziej złożonym elementem jest belka Timoszenki [7], dla której uwzględnia się również wpływ odkształceń postaciowych i bezwładności obrotowej. W elemencie tym przekrój nie pozostaje prostopadły do osi belki. Założenia teorii Timoszenki sprawdzają się w przypadku belek krępych lub złożonych i są skuteczne przy przewidywaniu globalnych zachowań, natomiast nie uwzględniają zjawisk lokalnych tj. deplanacji.

Najbardziej ogólnym elementem belkowym jest belka Własowa [8]. Jej opis uwzględnia kolejny stopień swobody jakim jest deplanacja oraz siłę wewnętrzną w postaci bimomentu. Nie jest więc zachowana zasada płaskich przekrojów, która jest fundamentem opisu zginania pręta o przekroju zwartym. Stosowany jest głównie do przekrojów cienkościennych otwartych, w celu uwzględnienia lokalnych zjawisk, jak zwichrzenie czy utrata stateczności giętnoskrętnej. Charakterystycznym punktem przekroju cienkościennego jest środek ścinania, ponieważ nie musi się on pokrywać się ze środkiem ciężkości, następu- 
je sprzężenie postaci drgań własnych. Wraz z uwzględnieniem teorii Timoszenki element Własowa stanowi uogólniony element belkowy (prętowy).

Należy jednak zwrócić uwagę na różnice w modelowaniu belek kompozytowych względem tradycyjnych modeli belkowych. Te wszystkie stosowane od lat zasady w tym przypadku nie są już aktualne, co bezpośrednio związane jest $\mathrm{z}$ anizotropią materiału.

Opracowanie modelu 1-D opisującego dynamiczne zachowanie cienkościennych elementów kompozytowych od lat jest tematem poruszanym i rozwijanym m.in. w publikacjach [9-14].

W artykułach $[9,10]$ przedstawione są ogólne równania ruchu opisujące drgania podłużne, skrętne oraz giętne pionowe i poziome.

Następnie w pracach [11-14] budowany jest model analityczny cienkościennej belki kompozytowej o przekroju bisymetrycznym. Wykorzystując zasadę Hamiltona opisane są drgania własne [12]: podłużne, giętne, skrętne oraz uwzględniające wpływ bimomentu (deplanację).

W dalszych rozważaniach autorzy uwzględniają w swoich równaniach wpływ sił tnących [13]. Natomiast w artykule [14] otrzymano najbardziej ogólne równania ruchu dla belki kompozytowej uwzględniające wszystkie sprzężenia wynikające $\mathrm{z}$ anizotropii materiału. Równań jest 7 , co wynika z liczby stopni swobody uwzględniającej deplanację.

\section{Obliczenia częstotliwości drgań własnych układów prętowych o przekroju prostokątnym}

\subsection{Opis założeń}

Przeprowadzono obliczenia dla belki o przekroju cienkościennym zamkniętym typu skrzynkowego prostokątnego o wymiarach w przekroju $700 \mathrm{~mm}$ x $1000 \mathrm{~mm}$. Wymiary przekroju przyjęto sugerując się dźwigarami istniejącego mostu kompozytowego w Błażowej. Przekrój składa się z 4 warstw laminatu o grubości 4x4mm, o różnej orientacji włókien (Rys. 1). Analizę przeprowadzono dla różnych wariantów schematów statycznych: belka obustronnie utwierdzona, przegubowo podparta i wspornik, dla rozpiętości $12 \mathrm{~m}$ i $24 \mathrm{~m}$. Dane materiałowe przyjęto dla przykładowego laminatu CFRP, na podstawie [14]: $\mathrm{E}_{1}=141,9 \mathrm{GPa}$, $\mathrm{E}_{2}=9,78 \mathrm{GPa}, v_{12}=0,42, \mathrm{G}_{12}=6,13 \mathrm{GPa}$ i $\rho=1445 \mathrm{~kg} / \mathrm{m}^{3}$.

Zbudowano modele powłokowe i odpowiadające im modele prętowe. W modelach powłokowych uwzględniona została ortotropia warstw i ich różne warianty ułożenia: $\left[0_{4}\right],\left[45_{4}\right],\left[0_{2} / 45_{2}\right],\left[45_{2} / 0_{2}\right],\left[0 / 45_{2} / 0\right],\left[45 / 0_{2} / 45\right],[0 / 45 / 0 / 45]$ i [45/0/45/0], które definiowano bezpośrednio przez wprowadzenie kątów orientacji włókien. W modelach belkowych dokonano homogenizacji materiału ustalając materiał izotropowy o średniej sztywności. Dla orientacji włókien [0 $0_{4}$ był to średni moduł $\mathrm{z}$ dwóch kierunków tj. $\mathrm{E}_{12}=75,84 \mathrm{GPa}$, dla [454] obliczono sztywność dla obróconych włókien korzystając ze wzorów w [15] i otrzymano 
$\mathrm{E}_{1}=\mathrm{E}_{2}=15,02 \mathrm{GPa}$, stąd średni moduł jest taki sam. Natomiast wszystkie pozostałe przypadki ułożenia warstw ze względu na to, że udziały powierzchniowe warstw o kącie orientacji włókien $0^{\circ}$ i $45^{\circ}$ są w przybliżeniu sobie równe, sprowadzono do jednego przypadku o uśrednionym $\mathrm{E}$ z poprzednich przykładów tj. $\mathrm{E}=45,43 \mathrm{GPa}$.

Dodatkowo przeanalizowano tę samą belkę $\mathrm{z}$ usztywnieniami $\mathrm{w}$ postaci przepon wewnętrznych z laminatu o 4 warstwach [0 $0_{4}$ ] umieszczonych co $2 \mathrm{~m}$ na długości i na skrajach belki (Rys. 2). W przypadku modeli prętowych przepony uwzględniono w postaci miejscowej zmiany definicji przekroju na lity o grubości $16 \mathrm{~mm}$, dokładnie w miejscach ich wystąpienia.

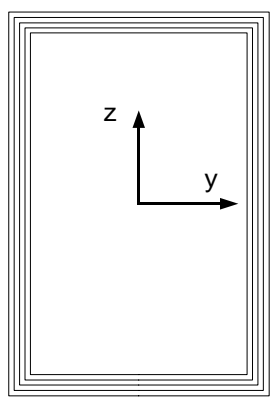

Rys. 1. Przekrój belki

Fig. 1. Beam cross section

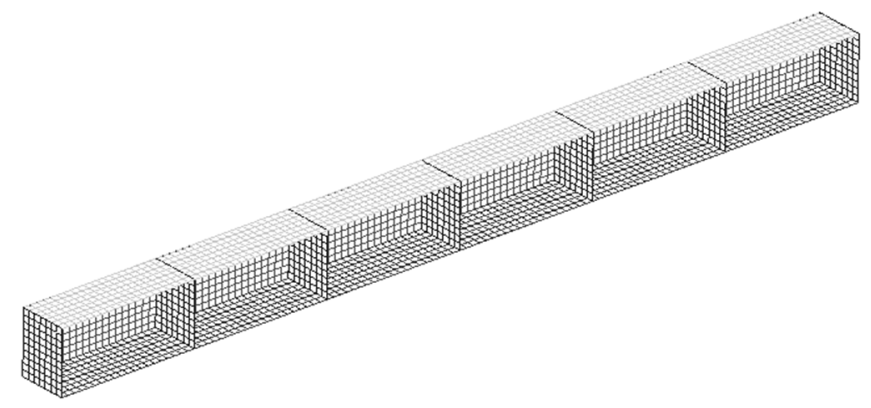

Rys. 2. Model powłokowy belki z usztywnieniami (widok bez jednej ścianki)

Fig. 2. Shell model of the beam with diaphragms (inside view)

Więzy podporowe dla modeli powłokowych zdefiniowane zostały na samej powłoce. Zrealizowano je blokując przesuwy we wszystkich kierunkach xyz dla utwierdzeń na wszystkich skrajnych krawędziach, dla belki przegubowej w dolnych krawędziach. Dla modeli prętowych więzy zdefiniowano w osi, dla utwierdzeń zablokowano zarówno możliwości przesuwu, jak i obrotu w każdym kierunku, dla przegubów wszystkie możliwości przesuwu i obrót na kierunku x. Blokada obrotu x wynika z liniowego mocowania belki na jej szerokości.

\subsection{Wyniki}

\subsubsection{Porównanie modeli dla różnych schematów statycznych}

Dla tak zdefiniowanych modeli cienkościennych obliczono parametry dynamiczne dla różnych wariantów podparcia i różnych długości - obliczenia przeprowadzono systemem ADINA. Wyniki przedstawiono jako zestawione tabelarycznie częstotliwości drgań własnych i opisy ich dominujących postaci. 
Tabela 1. Częstotliwości drgań własnych [Hz] belki o długości $12 \mathrm{~m}$ i ułożeniu warstw [04]

Table 1 . Natural frequencies $[\mathrm{Hz}]$ of a $12 \mathrm{~m}$ long beam with $\left[0_{4}\right]$ ply orientation

\begin{tabular}{|c|c|c|c|c|c|c|c|}
\hline & \multicolumn{6}{|c|}{ Model powłokowy } & \\
\hline & \multicolumn{2}{|c|}{ obustronnie utw. } & \multicolumn{2}{|c|}{ przegubowo podp. } & \multicolumn{2}{|c|}{ wspornik } & \\
\hline & bez & usztyw. & bez & usztyw. & bez & usztyw. & \\
\hline 1 & 24,9 & 35,7 & 5,74 & 29,1 & 10,2 & 9,7 & \\
\hline 2 & 25,6 & 39,3 & 24,5 & 38,7 & 13,5 & 12,7 & \\
\hline 3 & 26,8 & 40,2 & 24,9 & 39,3 & 16,6 & 34,8 & \\
\hline 4 & 28,11 & 42,2 & 25,3 & 40,2 & 24,7 & 38 & \\
\hline \multirow[t]{2}{*}{5} & 28,82 & 43,5 & 26,2 & 42,2 & 25,2 & 39,3 & \\
\hline & \multicolumn{6}{|c|}{ Model prętowy } & \\
\hline 1 & 52,1 & 50 & 23 & 22 & 8,2 & 7,7 & \\
\hline 2 & 68,2 & 65,6 & 30,1 & 29 & 10,8 & 10,2 & giętne $\mathrm{xy}$ \\
\hline 3 & 142,1 & 136,6 & 91,1 & 87,3 & 51 & 48,1 & giętne $\mathrm{xz}$ \\
\hline 4 & 150 & 143 & 119 & 114 & 66,5 & 62,8 & skrętne \\
\hline 5 & 185 & 178 & 150 & 143 & 75,1 & 73,3 & drgania ścianek \\
\hline
\end{tabular}

Tabela 2. Częstotliwości drgań własnych [Hz] belki długości 24m i ułożeniu warstw [04]

Table 2. Natural frequencies $[\mathrm{Hz}]$ of a $24 \mathrm{~m}$ long beam with [04] ply orientation

\begin{tabular}{|c|c|c|c|c|c|c|c|}
\hline & \multicolumn{6}{|c|}{ Model powłokowy } & \\
\hline & \multicolumn{2}{|c|}{ obustronnie utw. } & \multicolumn{2}{|c|}{ przegubowo podp } & \multicolumn{2}{|c|}{ wspornik } & \\
\hline & bez & usztyw. & bez & usztyw. & bez & usztyw. & \\
\hline 1 & 14 & 13,8 & 4,3 & 10,4 & 2,8 & 2,6 & \\
\hline 2 & 18,6 & 18 & 12,9 & 12,6 & 3,6 & 3,5 & \\
\hline 3 & 18,7 & 30,5 & 14 & 27 & 14,3 & 14,4 & \\
\hline 4 & 24,8 & 35 & 14,3 & 32,2 & 14,6 & 17,5 & \\
\hline \multirow[t]{2}{*}{5} & 24,9 & 39,1 & 17,7 & 33,2 & 18,6 & 18,8 & \\
\hline & \multicolumn{6}{|c|}{ Model prętowy } & \\
\hline 1 & 13,1 & 12,5 & 5,8 & 5,5 & 2,1 & 2 & \\
\hline 2 & 17,1 & 16,5 & 7,6 & 7,2 & 2,7 & 2,6 & giętne $x y$ \\
\hline 3 & 35,9 & 34,4 & 23 & 22 & 12,8 & 12,2 & giętne $\mathrm{xz}$ \\
\hline 4 & 47 & 45,1 & 30,1 & 28,9 & 16,8 & 16 & skrętne \\
\hline 5 & 70,1 & 67,2 & 51,5 & 49,4 & 35,8 & 34 & drgania ścianek \\
\hline
\end{tabular}

Analizę przeprowadzono w celu oceny wpływu schematu statycznego na częstotliwości drgań własnych belki (Tab. 1). Dla modeli powłokowych belek obustronnie utwierdzonej i przegubowo podpartej wśród pierwszych pięciu postaci drgań pojawiają się głównie formy drgań samych ścianek. Wprowadzenie 
przepon powoduje zwiększenie częstotliwości drgań ścianek i drgań skrętnych, a obniżenie częstotliwości drgań giętnych, co można zaobserwować dla schematu wspornika.

Następnie przeprowadzono tę samą analizę dla belki dwa razy dłuższej o identycznych założeniach dotyczących przekroju, a tym samym smuklejszej (Tab. 2). Wśród pierwszych pięciu postaci rzadziej występowały postacie drgań samych ścianek (chyba, że w sprzężeniu $\mathrm{z}$ innymi formami), a wprowadzenie usztywnień miało mniejszy wpływ na zmianę ich częstotliwości niż w przypadku belki krępej.

\subsubsection{Porównanie dla różnych kątów ułożenia warstw}

Kolejnym krokiem była analiza wpływu kąta ułożenia włókien w ściankach przekroju na wartości częstotliwości drgań własnych. Poniżej (Rys. 3 a i b) przedstawiono przykładowe wykresy tych zależności dla dwóch belek o schemacie wspornika, o długości $12 \mathrm{~m}$ i $24 \mathrm{~m}$. Postacie drgań oznaczono następująco: $\mathrm{BH}$-drgania giętne poziome, BV- drgania giętne pionowe, T- drgania skrętne.

W obu przypadkach częstotliwości drgań giętnych pionowych i poziomych maleją w takim samym stosunku dla wartości kąta od 0 do 60 stopni do ok. 0,3 wartości początkowej. W zakresie od 60 do 90 stopni nie widać już istotnych zmian. Częstotliwości drgań skrętnych rosną zaś dla kąta od 0 do ok. 60 stopni. Następnie, w przedziale od 60 do 90 stopni maleją, ale łagodniej. Dla belki o długości $12 \mathrm{~m}$ częstotliwość drgań skrętnych osiąga ponad dwukrotność swojej początkowej wartości, a w przypadku smuklejszej belki górna wartość nie przekracza 1,4.
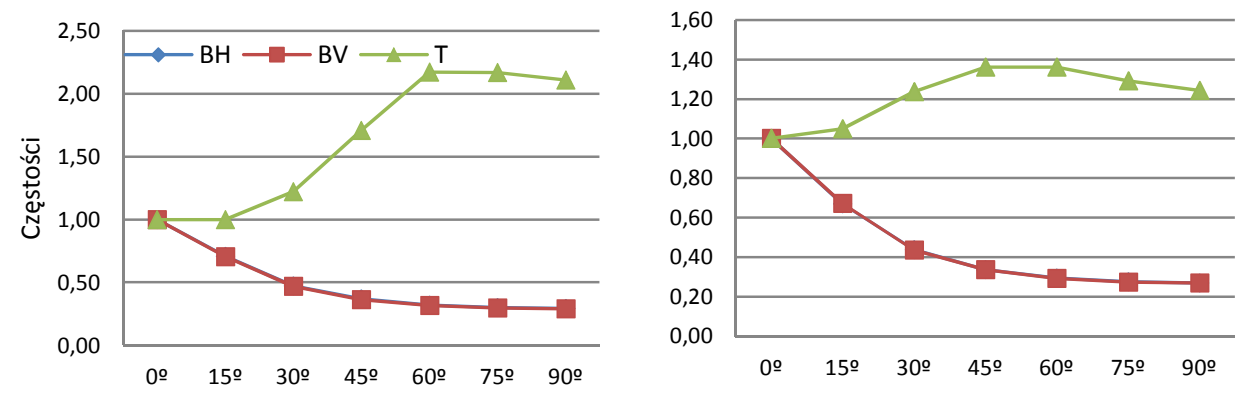

Rys. 3. Wykres zależności częstości unormowanych $\frac{\omega_{\alpha}}{\omega_{o}}$ od kąta ułożenia włókien dla wspornika: a) $12 \mathrm{~m}$, b) $24 \mathrm{~m}$

Fig. 3. Variation of the normalized natural frequencies $\frac{\omega_{\alpha}}{\omega_{o}}$ with respect to fiber angle change of a cantilever beam: a) $12 \mathrm{~m}$, b) $24 \mathrm{~m}$ long

Widać tutaj jak duże znaczenie ma orientacja włókien nośnych w warstwach laminatu. Stąd kolejny etap analizy, którym było uwzględnienie różnych warian- 
tów ułożenia warstw. Jak już wspomniano w podpunkcie 3.1., dla modeli prętowych były jedynie trzy warianty: wszystkie warstwy o kącie orientacji $0^{\circ}$ lub $45^{\circ}$ oraz mieszane w stosunku 50:50. Dla modeli powłokowych kombinacji ułożenia warstw o przybliżonym stosunku powierzchni przekroju 50:50 było 6 .

Tabela 3. Częstotliwości drgań własnych w zależności od orientacji włókien w warstwach [Hz]

Table 3. Natural frequencies for different stacking sequences [Hz]

\begin{tabular}{|c|c|c|c|c|c|c|c|c|c|c|}
\hline & \multicolumn{10}{|c|}{ Rozpiętość 12m } \\
\hline & \multicolumn{2}{|c|}{$\left[45_{2} / 0_{2}\right]$} & \multicolumn{2}{|c|}{$\left[0_{2} / 45_{2}\right]$} & \multicolumn{2}{|c|}{$\begin{array}{c}{\left[0 / 45_{2} / 0\right]} \\
\mathrm{i}\left[45 / 0_{2} / 45\right]\end{array}$} & \multicolumn{2}{|c|}{$[0 / 45 / 0 / 45]$} & \multicolumn{2}{|c|}{$[45 / 0 / 45 / 0]$} \\
\hline & bez & usztyw. & bez & usztyw. & bez & usztyw. & bez & usztyw. & bez & usztyw. \\
\hline 1 & 8,2 & 7,8 & 8,1 & 7,7 & 8,3 & 7,8 & 8,2 & 7,8 & 8,3 & 7,8 \\
\hline 2 & 10,8 & 10,2 & 10,7 & 10,1 & 10,9 & 10,2 & 10,8 & 10,2 & 10,9 & 10,2 \\
\hline 3 & 20,1 & 37,8 & 20,1 & 37,3 & 28,6 & 40,2 & 23,6 & 39,2 & 23,6 & 39,5 \\
\hline 4 & 32,2 & 45,5 & 32,1 & 45 & 40 & 47,8 & 37 & 47,9 & 37,4 & 47,5 \\
\hline \multirow[t]{2}{*}{5} & 32,9 & 45,7 & 32,9 & 45,2 & 42,3 & 53,7 & 38,2 & 52,9 & 37,7 & 53,2 \\
\hline & \multicolumn{10}{|c|}{ Rozpiętość 24m } \\
\hline 1 & 2,1 & 2 & 2,1 & 2 & 2,1 & 2 & 2,1 & 2 & 2,1 & 2 \\
\hline 2 & 2,8 & 2,6 & 2,8 & 2,6 & 2,8 & 2,6 & 2,8 & 2,6 & 2,8 & 2,6 \\
\hline 3 & 12,6 & 12,1 & 12,4 & 11,9 & 12,7 & 12,1 & 12,6 & 12 & 12,7 & 12,1 \\
\hline 4 & 16,6 & 15,8 & 16,4 & 15,6 & 16,6 & 15,8 & 16,5 & 15,7 & 16,6 & 15,8 \\
\hline 5 & 18,7 & 23,7 & 18,7 & 24,1 & 23 & 24 & 21,2 & 24,1 & 21,2 & 23,9 \\
\hline
\end{tabular}

Identyczne wyniki otrzymano dla orientacji włókien [0/45/0] i [45/02/45] w całym przekroju (Tab. 3). Drobne różnice (do 0,5 Hz) zanotowano dla przypadków [0/45/0/45] i [45/0/45/0] oraz $\left[02 / 45_{2}\right]$ i $\left[45_{2} / 0_{2}\right]$.

Dla belki o rozpiętości $12 \mathrm{~m}$ dwie pierwsze częstotliwości są porównywalne dla wszystkich przypadków. Symetryczne ułożenie warstw w ściankach (przypadki $\left[0 / 45_{2} / 0\right]$ i $\left[45 / 0_{2} / 45\right]$ ) zapewnia większą sztywność giętną samych ścianek, im bardziej warstwy są zróżnicowane względem osi ścianek tym ta sztywność jest mniejsza. Dla belki smuklejszej $(24 \mathrm{~m})$ wszystkie analizowane częstotliwości drgań giętnych są bardzo podobne. Różnice widać w drganiach skrętnych, gdzie dla przekrojów ze ściankami o niesymetrycznym układzie warstw częstotliwości są niższe.

Porównano także częstotliwości drgań dla obu typów modeli w zależności od ułożenia warstw laminatu (Tab. 4), dla belek wspornikowych o długościach $12 \mathrm{~m}$ i $24 \mathrm{~m}$. 
Tabela 4. Porównanie częstotliwości drgań własnych [Hz] dla modeli powłokowych i prętowych belki kompozytowej o schemacie wspornika

Table 4. Comparison of natural frequencies [Hz] for shell and beam models of a cantilever composite beam

\begin{tabular}{|c|c|c|c|c|c|c|c|c|}
\hline & \multicolumn{4}{|c|}{ Rozpiętość 12m } & \multicolumn{4}{|c|}{ Rozpiętość 24m } \\
\hline & \multicolumn{2}{|c|}{ model prętowy } & \multicolumn{2}{|c|}{ model powłokowy } & \multicolumn{2}{|c|}{ model prętowy } & \multicolumn{2}{|c|}{ model powłokowy } \\
\hline & \multicolumn{8}{|c|}{ wszystkie warstwy $0^{\circ}$} \\
\hline & bez & usztyw. & bez & usztyw. & bez & usztyw. & bez & usztyw. \\
\hline 1 & 8,2 & 7,7 & 10,2 & 9,7 & 2,1 & 2 & 2,8 & 2,6 \\
\hline 2 & 10,8 & 10,2 & 13,5 & 12,7 & 2,7 & 2,6 & 3,6 & 3,5 \\
\hline 3 & 51 & 48,1 & 16,6 & 34,8 & 12,8 & 12,2 & 14,3 & 14,4 \\
\hline 4 & 66,5 & 62,8 & 24,7 & 38 & 16,8 & 16 & 14,6 & 17,5 \\
\hline \multirow[t]{3}{*}{5} & 75,1 & 73,3 & 25,2 & 39,3 & 35,8 & 34 & 18,6 & 18,8 \\
\hline & \multicolumn{8}{|c|}{ wszystkie warstwy $\mathbf{4 5}^{\circ}$} \\
\hline & bez & usztyw. & bez & usztyw. & bez & usztyw. & bez & usztyw. \\
\hline 1 & 3,6 & 3,4 & 3,7 & 3,5 & 0,9 & 0,9 & 0,9 & 0,9 \\
\hline 2 & 4,8 & 4,5 & 4,9 & 4,6 & 1,2 & 1,1 & 1,2 & 1,2 \\
\hline 3 & 22,7 & 21,4 & 22,1 & 21,1 & 5,7 & 5,4 & 5,8 & 5,5 \\
\hline 4 & 29,6 & 27,9 & 28,5 & 27,4 & 7,5 & 7,1 & 7,6 & 7,2 \\
\hline \multirow[t]{3}{*}{5} & 36 & 35,2 & 29 & 38,8 & 16 & 15,2 & 16 & 15,2 \\
\hline & \multicolumn{8}{|c|}{ dwie warstwy $0^{\circ}$ i dwie warstwy $45^{\circ}$} \\
\hline & bez & usztyw. & bez & usztyw. & bez & usztyw. & bez & usztyw. \\
\hline 1 & 6,2 & 5,9 & 8,3 & 7,8 & 1,6 & 1,5 & 2,1 & 2 \\
\hline 2 & 8,2 & 7,7 & 10,9 & 10,2 & 2,1 & 2 & 2,8 & 2,6 \\
\hline 3 & 38,8 & 36,6 & 28,6 & 40,2 & 9,8 & 9,3 & 12,7 & 12,1 \\
\hline 4 & 50,7 & 47,8 & 40 & 47,8 & 12,8 & 12,2 & 16,6 & 15,8 \\
\hline 5 & 59,8 & 58,4 & 42,3 & 53,7 & 27,3 & 26 & 23 & 24 \\
\hline
\end{tabular}

Obrócenie warstw o $45^{\circ}$ powoduje obniżenie częstotliwości drgań giętnych, a dodatkowo w przypadku modeli powłokowych zwiększenie sztywności na skręcanie. Z kolei w modelach prętowych $\mathrm{G}$ zależy od $\mathrm{E}$ wprost proporcjonalnie, a więc częstotliwości drgań skrętnych maleją. Porównując częstotliwości drgań giętnych dla obu modeli można zauważyć największą zgodność. Wynika to $\mathrm{z}$ faktu, że przy włóknach obróconych o $45^{\circ}$ stosunek E1/E2 jest równy 1.

W przypadku mieszanych warstw ich układ dla modelu prętowego nie został wzięty pod uwagę. Do porównania przyjęto model z kodem orientacji $\left[0 / 45_{2} / 0\right]$ i $\left[45 / 0_{2} / 45\right]$. Poziom zgodności jest porównywalny jak dla przypadku ze wszystkimi warstwami $0^{\circ}$.

Dla wszystkich układów warstw wyniki są bardziej zgodne dla belki smuklejszej. 


\section{Analiza dynamiczna dźwigara kładki kompozytowej}

Przedstawiono dodatkowo przykład analizy dynamicznej opisany w [16, 17]. Dotyczy on belki z kompozytu FRP (Rys.5), będącej fragmentem testowym dźwigara kładki dla pieszych. Składa się ona z dźwigara skrzynkowego, pomostu oraz usztywnień w postaci przepon i zewnętrznych żeberek. Belka wykonana jest głównie z naprzemiennie ułożonych laminatów szklanych i węglowych, a ścianki i pomost są częściowo wypełnione pianką. Dokładny opis belki znajduje się w [16].

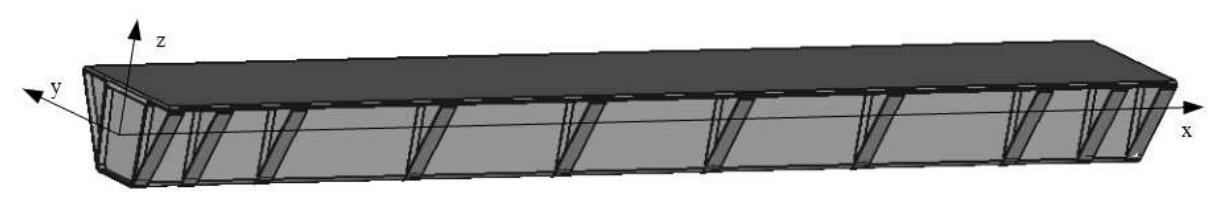

Rys. 5. Widok belki testowej bez podparcia (wykonane w programie FreeCAD) [16]

Fig. 5. The tested beam without support (FreeCAD) [16]

W celu zbadania dynamicznego zachowania belki zbudowano ciąg modeli prętowych, a wybrany porównano $\mathrm{z}$ modelem powłokowym i z wynikami otrzymanymi na drodze badań, podanymi w [17].

W założeniach dotyczących modelu prętowego usztywnienia uwzględniono jako masy skupione i zmianę sztywności na odcinkach ich występowania, natomiast wypełnienie betonem stref nadpodporowych tylko jako masy skupione. Uwzględniono wpływ ścinania, a deplanację przekroju ze względu na zamknięty przekrój belki, duże zagęszczenie usztywnień oraz wypełnienie betonem stref podporowych wykluczono. Przyjęto schemat belki wolnopodpartej.

Tabela 5. Wyniki końcowe dla wszystkich czterech modeli, na podstawie [16]

Table 5. The final results for all four models, based on [16]

\begin{tabular}{|c|c|c|c|c|}
\hline $\begin{array}{c}\text { Częstotliwości [Hz] } \\
\text { i postacie drgań } \\
\text { własnych }\end{array}$ & $\begin{array}{c}\text { materiał } \\
\text { jednorodny Ex } \\
\text { (1) }\end{array}$ & $\begin{array}{c}\text { materiał } \\
\text { jednorodny } \\
\text { Exy (2) }\end{array}$ & $\begin{array}{c}\text { materiał Ex, } \\
\text { charakterystyki } \\
\text { ważone (3) }\end{array}$ & $\begin{array}{c}\text { materiał Exy, } \\
\text { charakterystyki } \\
\text { ważone (4) }\end{array}$ \\
\hline 1 giętna xz & 20,1 & 16,5 & 13,8 & 13,8 \\
\hline 1 giętna xy & 22,5 & 18,4 & 16,0 & 15,5 \\
\hline 1 skrętna & 25,9 & 21,0 & 10,7 & 12,8 \\
\hline 2 giętna xz & 57,8 & 47,3 & 36,8 & 38,6 \\
\hline podłużna & 72,2 & 59,1 & 57,4 & 56,3 \\
\hline 2 skrętna & 89,1 & 72,6 & 33,0 & 39,6 \\
\hline
\end{tabular}


Dokonano homogenizacji materiału, a obliczenia przeprowadzono dla dwóch jego wariantów: z modułem Younga na podstawie modułów Ex tkanin i z modułem uśrednionym z Ex i Ey. Również charakterystyki przekroju obliczono na dwa sposoby: jak dla przekroju jednolitego i jak dla przekroju z dwóch różnych materiałów, tzw. charakterystyki ważone. Wyniki dla poszczególnych modeli zestawiono w postaci częstotliwości (Tab. 5).

Częstotliwości dla wariantu 2. stanowią ok. $82 \%$ wartości wyników dla wariantu 1. Dla modeli z ważonymi charakterystykami przekroju częstotliwości są niższe od tych $\mathrm{z}$ przyjętym uśrednionym materiałem jednorodnym. Ponadto zmienia się ich kolejność ze względu na obniżenie się częstotliwości drgań skrętnych względem giętnych. Wariant 4 . ma większe wartości częstotliwości drgań skrętnych od wariantu 3., a pozostałe mniejsze.

Tabela 6. Porównanie obliczonych i zmierzonych częstotliwości, na podstawie [17]

Table 6. Comparison of calculated and measured frequencies, based on [17]

\begin{tabular}{|c|c|c|c|c|c|c|}
\cline { 2 - 6 } \multicolumn{1}{c|}{} & $\begin{array}{c}\text { Częst. } \\
\text { mierzone } \\
{[\mathbf{H z}]}\end{array}$ & Postać drgań & $\begin{array}{c}\text { Częst. modelu } \\
\text { powłokowego } \\
{[\mathbf{H z}]}\end{array}$ & $\begin{array}{c}\text { Postać } \\
\text { drgań }\end{array}$ & $\begin{array}{c}\text { Częst. modelu } \\
\text { prętowego (2) } \\
{[\mathbf{H z}]}\end{array}$ & $\begin{array}{c}\text { Postać } \\
\text { drgań }\end{array}$ \\
\hline $\mathbf{1}$ & 9,7 & giętna- xy & 16,3 & giętna - & 16,5 & giętna - xz \\
\hline $\mathbf{2}$ & 16,1 & giętna - xz & 17,8 & giętna - & 18,4 & giętna - xy \\
\hline $\mathbf{3}$ & 20,8 & skrętna & 26,8 & skrętna & 21,0 & skrętna \\
\hline $\mathbf{4}$ & 26,2 & & 30,2 & skrętna & 47,3 & giętna - xz \\
\hline $\mathbf{5}$ & 31,0 & skrętna & 36,5 & giętna - & 59,1 & podłużna \\
\hline $\mathbf{6}$ & 33,9 & giętna - ukos & 43,5 & lokalna & 72,6 & skrętna \\
\hline
\end{tabular}

Najbliżej wartościom częstotliwości modelu powłokowego są te otrzymane dla uśrednionego Exy i charakterystyk geometrycznych jak dla materiału jednorodnego (wariant 2.). Porównanie wyników dla tego modelu z modelem powłokowym i wartościami pomierzonymi przedstawiono w Tab. 6.

Wartości częstotliwości dla pierwszej postaci giętnej w płaszczyźnie xz są porównywalne dla wszystkich przypadków. Natomiast dla pierwszej giętnej w płaszczyźnie xy wartość pomierzona odbiega od częstotliwości dla obu modeli (możliwa różnica w podparciu). Częstotliwość pierwszej postaci skrętnej dla modelu 1D jest bliższa zmierzonej niż ta dla modelu powłokowego. nią.

Kolejne wartości częstotliwości i postacie drgań znacznie się od siebie róż-

\section{Wnioski}

Niekwestionowaną zaletą modeli prętowych jest możliwość przeanalizowania wpływu na wyniki poszczególnych parametrów modelu. Jednak dotychczasowo stosowane modele prętowe mają pewne ograniczenia w kontekście opisu 
elementów cienkościennych wykonanych z materiału kompozytowego. W przypadku belek kompozytowych, nawet dla tych o zamkniętym przekroju bisymetrycznym występują sprzężenia postaci drgań. Znaczenie bowiem ma ułożenie warstw o danym kącie włókien nośnych, a więc o danych charakterystykach materiałowych, ale też stosunek sztywności na obu kierunkach (im bardziej zbliżony do 1 , tym bardziej przypomina zachowanie tradycyjnej belki). Co więcej, właściwy środek ścinania dla takiego przekroju nie jest tożsamy z geometrycznym środkiem ścinania. Pod uwagę trzeba wziąć symetrię ułożenia warstw w ściankach względem osi symetrii przekroju, jak i osi samych ścianek. W artykule [14] przedstawiono sprzężenie sześciu postaci drgań: giętnych na obu kierunkach, skrętnej, wpływy ścinania na obu kierunkach i deplanację, pomimo tego, że przekrój jest zamknięty, a belka utwierdzona na obu końcach. Przykład ten pokazuje, że deplanacja w takim przypadku nie może być pominięta. Podobnie z wpływami ścinania, nawet dla smukłych belek ich uwzględnienie wpływa na zmniejszenie wartości otrzymanych częstości własnych, o czym wspomniano również w [16, 17].

Podsumowując, wystarczającym do opisu belek smukłych o przekroju usztywnionym zdawałaby się belka Eulera-Bernoulliego, dla której wpływy ścinania są pomijalnie małe, a deplanacja nie występuje. Jednak, co widać w powyższych przykładach, w przypadku belek z materiałów kompozytowych dotychczasowo kształtowana intuicja inżynierska zawodzi i koniecznym jest opracowanie nowego modelu 1-D opisującego dynamiczne zachowanie cienkościennych elementów kompozytowych, co od lat jest tematem poruszanym i rozwijanym m.in. w publikacjach [9-14].

\section{Literatura}

[1] http://www.nbi.com.pl/assets/NBI-pdf/2015/3_60_2015/PDF/23_Wykorzystanie_ kompozytow_w_budownictwie.pdf, dostęp 27-02-2017.

[2] Lewandowski R. Dynamika konstrukcji budowlanych. Wydawnictwo Politechniki Poznańskiej, Poznań 2006.

[3] Gjelsvik A.: The theory of thin walled bars, John Wiley\&Sons, New York, 1981.

[4] Doyle J.F.: Nonlinear analysis of thin-walled structures, Springer, New York, 2001.

[5] Stojek Z., Sobol K., Ziemiański L.: Makromodele kontynualne w analizie wpływów dynamicznych na poziome drgania wielokondygnacyjnych konstrukcji ramowych, Wpływ wibracji na otoczenie - Wibrotechnika, Kraków-Janowice 1986, 135-145.

[6] Timoshenko S. P. On the correction for shear of the differential equation for transverse vibration of prismatic bars. London 1921, Philosophical Magazine Series 6, vol. 41, no. 245, pp. 744-746.

[7] Timoshenko S. P. History of strength of materials. McGraw-Hill New York, 1953.

[8] Vlasov, V. Z. Thin-Walled Elastic Beams. Jerusalem: Israel Program for Scientific Translations, 1961. 
[9] Armanios EA, Badir AM.: Free vibration analysis of anisotropic thin-walled closedsection beams. AIAA J 1995, 33(10):1905-10.

[10] Dancila DS, Armanios EA. The influence of coupling on the free vibration of anisotropic thin-walled closed-section beams. Int J Solids Struct 1998, 35(23):3105-19.

[11] Vo TP, Lee J. Flexural-torsional behavior of thin-walled composite box beams using shear-deformable beam theory. Engineering Structures 2008, 30(7):1958-68.

[12] Vo TP, Lee J. Flexural-torsional behavior of thin-walled closed-section composite box beams. Engineering Structures 2007, 29(8):1774-82.

[13] Vo TP, Lee J. Free vibration of thin-walled composite box beams. Composite Structures 2007, 84(1):11-20.

[14] Vo TP, Lee J and Ahn N.: On six fold coupled vibrations of thin-walled composite box beams. Composite Structures 2009, 89, pp. 524-535.

[15] German J. Podstawy Mechaniki Kompozytów Włóknistych. Wydawnictwo Politechniki Krakowskiej. Kraków 1996.

[16] Markiewicz B., Ziemiański L.: Numerical modal analysis of the FRP coposite beam, Czasopismo Inżynierii Lądowej, Środowiska i Architektury - Journal of Civil Engineering, Environment and Architecture, JCEEA, tom XXXII 62 (4/2015), pp. 281-292, DOI: 10.7862/rb.2015.195.

[17] Markiewicz B., Ziemiański L., Kulpa M.: Calculated and measured dynamic properties of the FRP composite beam, PCM-CMM 2015 Book of Short Papers, Wyd. PTMTS, Gdańsk 2015, Vol. 1, pp. 401-402.

\section{DYNAMIC ANALYSIS OF THIN-WALLED COMPOSITE STRUCTURES}

\section{S u m m a r y}

The paper presents a dynamic analysis of closed thin-walled (CTW) section composite structures with different boundary conditions. Analysis is carried out with a use of shell models and corresponding simplified beam models.

The shell models include orthotrophy of the composite material and different fiber orientation angles in laminas. In the beam models the material is homogenized and treated as isotropic with mean material properties. The numerical analysis is also performed for the same beam with added internal diaphragms.

The results are presented in the form of natural frequencies and corresponding mode shapes. The effects of the boundary conditions, fiber angle and slenderness are studied. The results obtained for the shell models are compared with those for the simplified beam models.

Keywords: composite beam, thin-walled beam, beam element, FEM modeling, natural frequencies

Przestano do redakcji: 20.03.2017 r.

Przyjęto do druku: 28.04.2017 r. 